\title{
Photoluminescence Properties of Europium and Cerium Co-Doped Tantalum-Oxide Thin Films Prepared Using Co-Sputtering Method
}

\author{
Kenta Miura*, Tetsuhito Suzuki, Osamu Hanaizumi \\ Graduate School of Science and Technology, Gunma University, Kiryu, Japan \\ Email: " mkenta@gunma-u.ac.jp
}

Received 3 July 2015; accepted 4 August 2015; published 7 August 2015

Copyright (c) 2015 by authors and Scientific Research Publishing Inc.

This work is licensed under the Creative Commons Attribution-NonCommercial International License (CC BY-NC).

http://creativecommons.org/licenses/by-nc/4.0/

(c) () \&) Open Access

\section{Abstract}

We fabricated europium and cerium co-doped tantalum (V) oxide $\left(\mathrm{Ta}_{2} \mathrm{O}_{5}\right.$ : Eu, Ce) thin films using our co-sputtering method for the first time, and evaluated photoluminescence (PL) properties of the films after annealing at $600^{\circ} \mathrm{C}-1100^{\circ} \mathrm{C}$ for $20 \mathrm{~min}$. Four remarkable PL peaks at wavelengths of $600,620,700$, and $705 \mathrm{~nm}$ were observed from the film annealed at $900^{\circ} \mathrm{C}$. The intensities of the 700- and 705-nm peaks due to the ${ }^{5} D_{0} \rightarrow{ }^{7} F_{4}$ transition of Eu ${ }^{3+}$ were much stronger than those of the $600-\mathrm{nm}\left({ }^{5} D_{0} \rightarrow{ }^{7} F_{1}\right)$ and $620-\mathrm{nm}\left({ }^{5} D_{0} \rightarrow{ }^{7} F_{2}\right)$ peaks of the film annealed at $900^{\circ} \mathrm{C}$. It seems that energy transfer from $\mathrm{Ce}^{3+}$ to $\mathrm{Eu}^{3+}$ occurs in the film, and much energy is selectively used for the ${ }^{5} \mathrm{D}_{0}$ $\rightarrow{ }^{7} \mathbf{F}_{4}$ and ${ }^{5} D_{0} \rightarrow{ }^{7} F_{1}$ transitions. Such a $\mathrm{Ta}_{2} \mathrm{O}_{5}$ : Eu, Ce co-sputtered thin film seems to be used as a multi-functional coating film having both anti-reflection and down-conversion effects for realizing a high-efficiency silicon solar cell.

\section{Keywords}

Tantalum Oxide, Europium, Cerium, Co-Sputtering, Photoluminescence

\section{Introduction}

Tantalum (V) oxide $\left(\mathrm{Ta}_{2} \mathrm{O}_{5}\right)$ is a high-refractive-index material used in passive optical elements such as $\mathrm{Ta}_{2} \mathrm{O}_{5} /$ $\mathrm{SiO}_{2}$ multilayered wavelength filters for dense wavelength-division multiplexing (DWDM). It has also been used as a high-index material of $\mathrm{Ta}_{2} \mathrm{O}_{5} / \mathrm{SiO}_{2}$ multilayered photonic-crystal elements for the visible to nearinfrared range fabricated using the "autocloning" method based on radio-frequency (RF) bias sputtering [1] [2],

\footnotetext{
${ }^{*}$ Corresponding author.
}

How to cite this paper: Miura, K., Suzuki, T. and Hanaizumi, O. (2015) Photoluminescence Properties of Europium and Cerium Co-Doped Tantalum-Oxide Thin Films Prepared Using Co-Sputtering Method. Journal of Materials Science and Chemical Engineering, 3, 30-34. http://dx.doi.org/10.4236/msce.2015.38005 
and it can additionally be used as an anti-reflection coating material for silicon solar cells [3].

However, $\mathrm{Ta}_{2} \mathrm{O}_{5}$ has recently attracted much attention as an active optical material, since broad red photoluminescence (PL) spectra at wavelengths of 600 to $650 \mathrm{~nm}$ were observed from thermal-oxidized amorphous $\mathrm{Ta}_{2} \mathrm{O}_{5}$ thin films [4]. Many studies on rare-earth-doped $\mathrm{Ta}_{2} \mathrm{O}_{5}$ have also been conducted because $\mathrm{Ta}_{2} \mathrm{O}_{5}$ is a potential host material for new phosphors due to its lower phonon energy $\left(100-450 \mathrm{~cm}^{-1}\right)$ than other popular oxide materials (e.g. silicon dioxide $\left(\mathrm{SiO}_{2}\right)$ ) [5]. We have fabricated various rare-earth doped $\mathrm{Ta}_{2} \mathrm{O}_{5}$ thin films using simply co-sputtering of rare-earth oxide pellets and a $\mathrm{Ta}_{2} \mathrm{O}_{5}$ disc, and we obtained various PL properties from these rare-earth-doped $\mathrm{Ta}_{2} \mathrm{O}_{5}$ thin films [6]-[11]. We reported on red or orange PL from europium (Eu)-doped $\mathrm{Ta}_{2} \mathrm{O}_{5}\left(\mathrm{Ta}_{2} \mathrm{O}_{5}\right.$ : $\left.\mathrm{Eu}\right)$ thin films deposited using the same co-sputtering method [9]. In our recent study, we fabricated erbium (Er), Eu, and cerium (Ce) co-doped $\mathrm{Ta}_{2} \mathrm{O}_{5}\left(\mathrm{Ta}_{2} \mathrm{O}_{5}\right.$ : Er, Eu, Ce) thin films using co-sputtering of $\mathrm{Er}_{2} \mathrm{O}_{3}, \mathrm{Eu}_{2} \mathrm{O}_{3}, \mathrm{CeO}_{2}$ and $\mathrm{Ta}_{2} \mathrm{O}_{5}$, and observed yellow PL from a film annealed at $900^{\circ} \mathrm{C}$ [10]. The yellow light emission seemed to be obtained from the result of enhancement of the 550-nm (green) PL peak due to $\mathrm{Er}^{3+}$ by $\mathrm{Ce}^{3+}$ doping [12]. We also prepared Er and Ce co-doped $\mathrm{Ta}_{2} \mathrm{O}_{5}\left(\mathrm{Ta}_{2} \mathrm{O}_{5}\right.$ : Er, Ce) thin films using co-sputtering of $\mathrm{Er}_{2} \mathrm{O}_{3}, \mathrm{CeO}_{2}$ and $\mathrm{Ta}_{2} \mathrm{O}_{5}$. An enhanced green PL peak that seems to be sensitized by $\mathrm{Ce}^{3+}$ was observed from a film annealed at $900^{\circ} \mathrm{C}$ [11]. We can obtain $\mathrm{Ce}^{3+}$ from $\mathrm{CeO}_{2}$ (cerium (IV) oxide) pellets because a small amount of $\mathrm{Ce}^{3+}$ exists at the surface of $\mathrm{CeO}_{2}$ [13].

In this study, we fabricated Eu and Ce co-doped $\mathrm{Ta}_{2} \mathrm{O}_{5}\left(\mathrm{Ta}_{2} \mathrm{O}_{5}\right.$ : Eu, Ce) thin films using our co-sputtering method for the first time, and we evaluated PL properties of the films.

\section{Experimental}

$\mathrm{Ta}_{2} \mathrm{O}_{5}$ : Eu, Ce thin films were deposited using our RF magnetron sputtering system (ULVAC, SH-350-SE). A schematic figure of the system was presented in our previous report [7]. A $\mathrm{Ta}_{2} \mathrm{O}_{5}$ sintered-compact disc (Furuuchi Chemical Corporation, 99.99\% purity, diameter $100 \mathrm{~mm}$ ) was used as a sputtering target in the system. We placed an $\mathrm{Eu}_{2} \mathrm{O}_{3}$ sintered-compact pellet (Furuuchi Chemical Corporation, 99.9\% purity, diameter $20 \mathrm{~mm}$ ) and two $\mathrm{CeO}_{2}$ sintered-compact pellets (Furuuchi Chemical Corporation, 99.9\% purity, diameter $20 \mathrm{~mm}$ ) on the $\mathrm{Ta}_{2} \mathrm{O}_{5}$ disc as presented in Figure 1. They were co-sputtered by supplying RF power to the target. The flow rate of Ar gas introduced into the processing vacuum chamber was $15 \mathrm{sccm}$, and the pressure in the chamber during deposition was kept at $\sim 5.4 \times 10^{-4}$ Torr. The RF power supplied to the target was $200 \mathrm{~W}$. Fused-silica plates (ATOCK Inc., $1 \mathrm{~mm}$ thick) were used as substrates, and they were not heated during sputtering. The thicknesses of the films were set to be $\sim 1.5 \mu \mathrm{m}$ by adjusting the sputtering times of the films.

We subsequently annealed the $\mathrm{Ta}_{2} \mathrm{O}_{5}$ : Eu, Ce co-sputtered thin films in ambient air at $600^{\circ} \mathrm{C}, 700^{\circ} \mathrm{C}, 800^{\circ} \mathrm{C}$, $900^{\circ} \mathrm{C}, 1000^{\circ} \mathrm{C}$, or $1100^{\circ} \mathrm{C}$ for 20 min using an electric furnace (Denken, KDF S-70). We set the annealing time to 20 min because it was the proper condition for our Er-doped $\mathrm{Ta}_{2} \mathrm{O}_{5}\left(\mathrm{Ta}_{2} \mathrm{O}_{5}\right.$ : Er) films to obtain strong PL intensities [6] [8]. The PL spectra of the films were measured using a dual-grating monochromator (Roper Scientific, SpectraPro 2150i) and a CCD detector (Roper Scientific, Pixis: $100 \mathrm{~B}$, electrically cooled to $-80^{\circ} \mathrm{C}$ ). A He-Cd laser (Kimmon, IK3251R-F, wavelength $\lambda=325 \mathrm{~nm}$ ) was used to excite the films. The Eu and Ce concentrations of the films after annealing were measured using an electron probe micro-analyzer (EPMA) (Shimadzu, EPMA-1610). The X-ray diffraction (XRD) patterns of the films were recorded using an X-ray diffractometer (RIGAKU, RINT2200VF+/PC system).

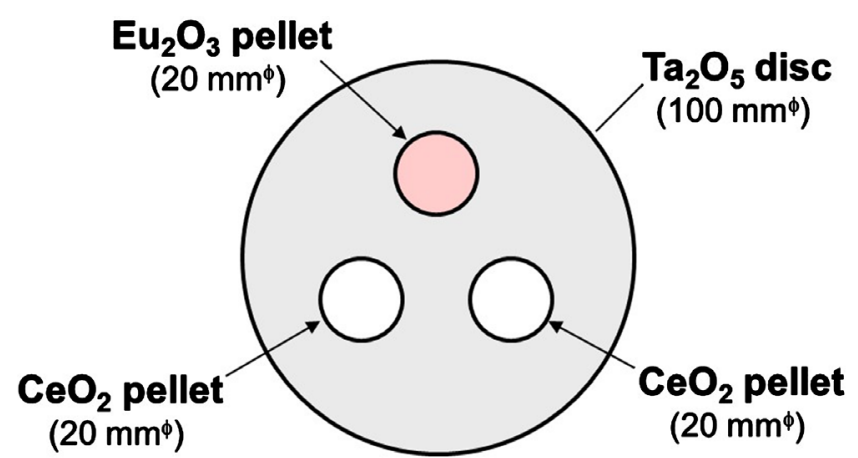

Figure 1. Schematic top view of the sputtering target for co-sputtering of an $\mathrm{Eu}_{2} \mathrm{O}_{3}$ pellet, two $\mathrm{CeO}_{2}$ pellets, and $\mathrm{Ta}_{2} \mathrm{O}_{5}$ disc. 


\section{Results and Discussion}

Figure 2 presents PL spectra of $\mathrm{Ta}_{2} \mathrm{O}_{5}$ : Eu, Ce films annealed at $600^{\circ} \mathrm{C}, 700^{\circ} \mathrm{C}, 800^{\circ} \mathrm{C}, 900^{\circ} \mathrm{C}, 1000^{\circ} \mathrm{C}$, or $1100^{\circ} \mathrm{C}$ for $20 \mathrm{~min}$. Four remarkable PL peaks at wavelengths of $600,620,700$, and $705 \mathrm{~nm}$ were observed only from the film annealed at $900^{\circ} \mathrm{C}$. No PL peak was observed from the films annealed at $600^{\circ} \mathrm{C}, 700^{\circ} \mathrm{C}, 800^{\circ} \mathrm{C}$, $1000^{\circ} \mathrm{C}$, or $1100^{\circ} \mathrm{C}$. The peaks at the wavelengths of 600 and $620 \mathrm{~nm}$ seem to be the results of the ${ }^{5} \mathrm{D}_{0} \rightarrow{ }^{7} \mathrm{~F}_{1}$ and ${ }^{5} \mathrm{D}_{0} \rightarrow{ }^{7} \mathrm{~F}_{2}$ transitions of $\mathrm{Eu}^{3+}$, respectively [9], and the peaks at the wavelength of 700 and $705 \mathrm{~nm}$ seem to be due to the ${ }^{5} \mathrm{D}_{0} \rightarrow{ }^{7} \mathrm{~F}_{4}$ transition of $\mathrm{Eu}^{3+}$ [9]. We could not observe a remarkable peak around a wavelength of 650 nm due to the ${ }^{5} \mathrm{D}_{0} \rightarrow{ }^{7} \mathrm{~F}_{3}$ transition of $\mathrm{Eu}^{3+}$ that was observed in [9]. On the other hand, we found an additional $705-\mathrm{nm}$ peak from the film annealed at $900^{\circ} \mathrm{C}$.

The Eu and Ce concentrations of the film annealed at $800^{\circ} \mathrm{C}$ were measured to be around 1.5 and $2.8 \mathrm{~mol} \%$, respectively. The concentrations may be almost the same as those of the films annealed at the other temperatures.

Figure 3 presents XRD patterns of the films annealed at $600^{\circ} \mathrm{C}$, $700^{\circ} \mathrm{C}$, or $800^{\circ} \mathrm{C}$ (Figure 3(a)) and those of the films annealed at $900^{\circ} \mathrm{C}, 1000^{\circ} \mathrm{C}$, or $1100^{\circ} \mathrm{C}$ (Figure $3(\mathrm{~b})$ ). The films annealed at $600^{\circ} \mathrm{C}, 700^{\circ} \mathrm{C}$, and $800^{\circ} \mathrm{C}$ seemed to be almost amorphous phases because no significant diffraction peak was observed from them as seen in Figure 3(a). On the other hand, three major peaks corresponding to the (0 01 1); $\beta-\mathrm{Ta}_{2} \mathrm{O}_{5}$ (orthorhombic), $(20$ 0 ); $\delta-\mathrm{Ta}_{2} \mathrm{O}_{5}$ (hexagonal), and (2 01 1) $\mathrm{Ta}_{2} \mathrm{O}_{5}$ phases were observed from the films annealed at $900^{\circ} \mathrm{C}$ [7]. These crystalline phases of $\mathrm{Ta}_{2} \mathrm{O}_{5}$ seem to be very important for obtaining significant PL peaks from our $\mathrm{Ta}_{2} \mathrm{O}_{5}$ : $\mathrm{Eu}$, Ce films annealed at $900^{\circ} \mathrm{C}$. Furthermore, other diffraction peaks due to $\mathrm{CeTa}_{7} \mathrm{O}_{19}$ and $\mathrm{EuTa}_{7} \mathrm{O}_{19}$ crystals were observed from the films annealed at $1000^{\circ} \mathrm{C}$ and $1100^{\circ} \mathrm{C}$. In particular, four peaks corresponding to the hexagonal

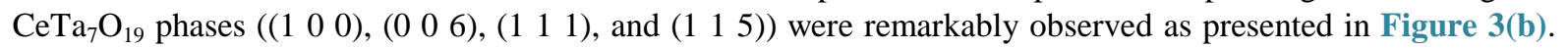
Therefore, it seems that the hexagonal $\mathrm{CeTa}_{7} \mathrm{O}_{19}$ phases should be avoided in order to obtain PL from our $\mathrm{Ta}_{2} \mathrm{O}_{5}$ : Eu, Ce films.

Figure 4 illustrates energy level diagrams of $\mathrm{Eu}^{3+}$ and $\mathrm{Ce}^{3+}[14]$ [15]. As presented in Figure 4, electrons are excited to the ${ }^{2} \mathrm{D}_{5 / 2}$ state by the He-Cd laser irradiation $(\lambda=325 \mathrm{~nm})$, and they relax to the ${ }^{2} \mathrm{D}_{3 / 2}$ state of $\mathrm{Ce}^{3+}$. Subsequently, energy transfer from the ${ }^{2} \mathrm{D}_{3 / 2}$ state of $\mathrm{Ce}^{3+}$ to the ${ }^{5} \mathrm{D}_{1}$ state of $\mathrm{Eu}^{3+}$ occurs, and the electrons relax

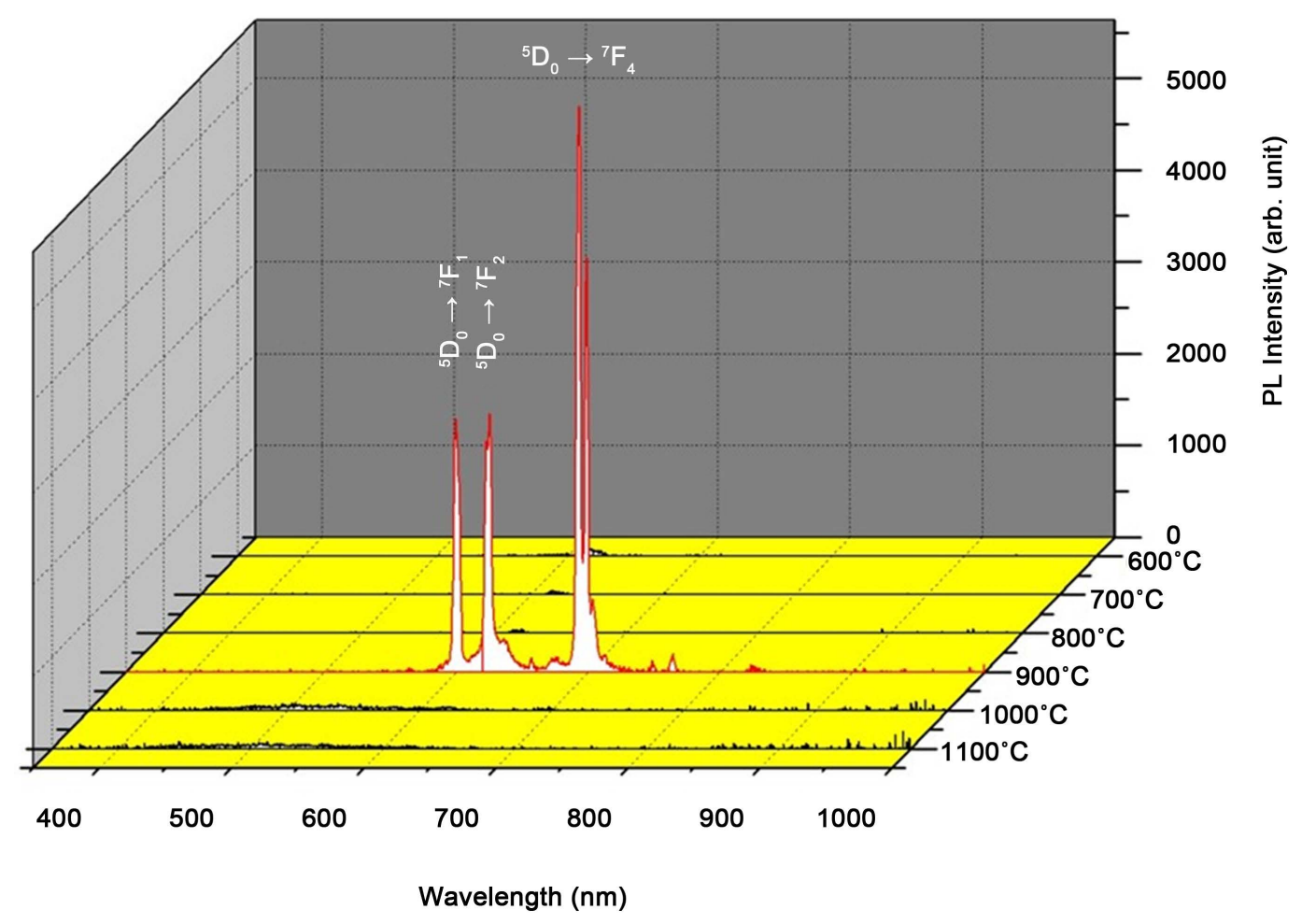

Figure 2. PL spectra of $\mathrm{Ta}_{2} \mathrm{O}_{5}$ : Eu, Ce co-sputtered thin films annealed at $600^{\circ} \mathrm{C}, 700^{\circ} \mathrm{C}, 800^{\circ} \mathrm{C}, 900^{\circ} \mathrm{C}$, $1000^{\circ} \mathrm{C}$, or $1100^{\circ} \mathrm{C}$. 


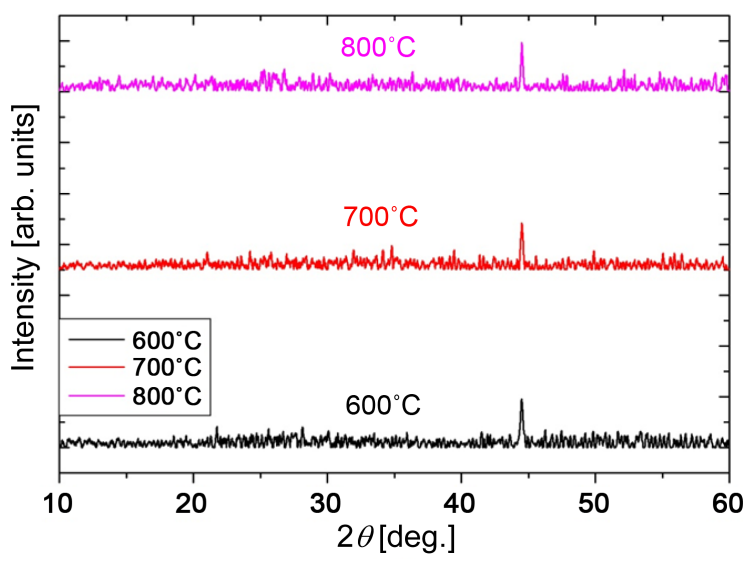

(a)

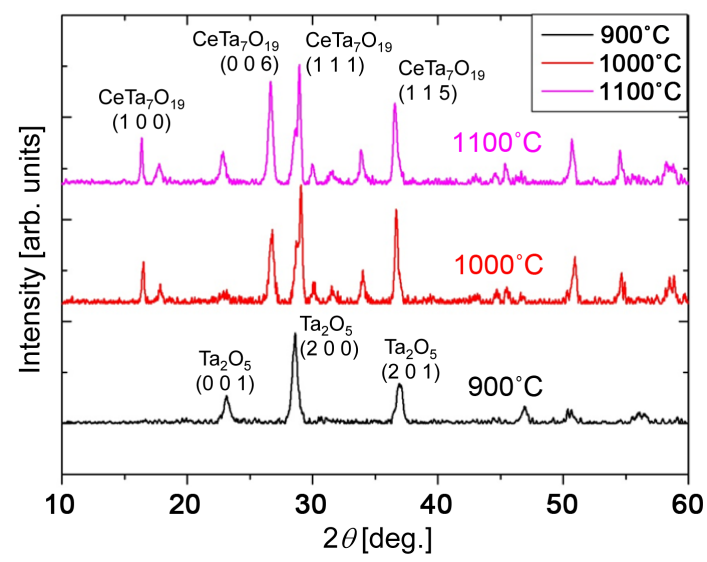

(b)

Figure 3. XRD patterns of $\mathrm{Ta}_{2} \mathrm{O}_{5}$ : Eu, Ce films annealed at (a) $600^{\circ} \mathrm{C}, 700^{\circ} \mathrm{C}$, or $800^{\circ} \mathrm{C}$ and (b) $900^{\circ} \mathrm{C}, 1000^{\circ} \mathrm{C}$, or $1100^{\circ} \mathrm{C}$.

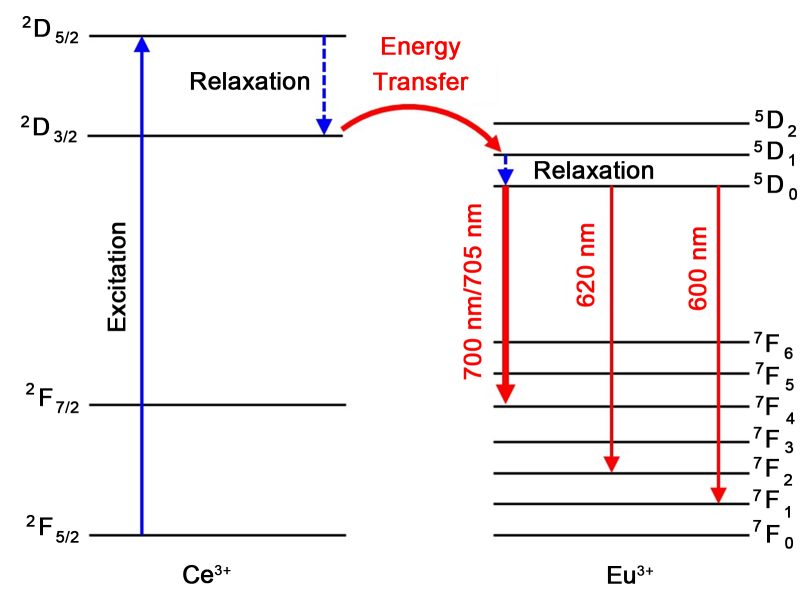

Figure 4. Energy level diagrams of $\mathrm{Eu}^{3+}$ and $\mathrm{Ce}^{3+}$.

to the ${ }^{5} \mathrm{D}_{0}$ state of Eu ${ }^{3+}$. Finally, the transitions of ${ }^{5} \mathrm{D}_{0} \rightarrow{ }^{7} \mathrm{~F}_{1},{ }^{5} \mathrm{D}_{0} \rightarrow{ }^{7} \mathrm{~F}_{2}$, and ${ }^{5} \mathrm{D}_{0} \rightarrow{ }^{7} \mathrm{~F}_{4}$ occur, and light emission at wavelengths of $600,620,700$, and $705 \mathrm{~nm}$ can be observed. In our previous study, the 620-nm peaks observed from our $\mathrm{Ta}_{2} \mathrm{O}_{5}$ : Eu co-sputtered thin films were much stronger than the other peaks around the wavelengths of 600 and $700 \mathrm{~nm}$ [9]. However, as seen in Figure 2, the intensities of the $600-\mathrm{nm}\left({ }^{5} \mathrm{D}_{0} \rightarrow{ }^{7} \mathrm{~F}_{1}\right)$ and $620-\mathrm{nm}\left({ }^{5} \mathrm{D}_{0} \rightarrow{ }^{7} \mathrm{~F}_{2}\right)$ peaks were almost the same, and the intensity of the 700- and 705-nm $\left({ }^{5} \mathrm{D}_{0} \rightarrow{ }^{7} \mathrm{~F}_{4}\right)$ was much stronger than that of the $620-\mathrm{nm}$ peak of the $\mathrm{Ta}_{2} \mathrm{O}_{5}: \mathrm{Eu}$, Ce co-sputtered thin film annealed at $900^{\circ} \mathrm{C}$. It seems that energy transfer from $\mathrm{Ce}^{3+}$ to $\mathrm{Eu}^{3+}$ occurs in the film, and much energy is selectively used for the ${ }^{5} \mathrm{D}_{0}$ $\rightarrow{ }^{7} \mathrm{~F}_{4}$ and ${ }^{5} \mathrm{D}_{0} \rightarrow{ }^{7} \mathrm{~F}_{1}$ transitions.

Such $\mathrm{Ta}_{2} \mathrm{O}_{5}$-based thin films seem to be used as high-refractive-index and light-emitting materials of "autocloning" photonic crystals that can be applied to novel light-emission devices [1], and they also seem to be used as multi-functional coating films having both anti-reflection [3] and down-conversion [16]-[18] effects for realizing high-efficiency silicon solar cells.

\section{Conclusion}

We fabricated $\mathrm{Ta}_{2} \mathrm{O}_{5}$ : Eu, Ce thin films using our co-sputtering method for the first time, and evaluated the PL properties of the films after annealing at $600^{\circ} \mathrm{C}-1100^{\circ} \mathrm{C}$ for $20 \mathrm{~min}$. Four remarkable PL peaks at wavelengths of $600,620,700$, and $705 \mathrm{~nm}$ were observed from the film annealed at $900^{\circ} \mathrm{C}$. The intensities of the $700-$ and 705-nm peaks due to the ${ }^{5} \mathrm{D}_{0} \rightarrow{ }^{7} \mathrm{~F}_{4}$ transition of $\mathrm{Eu}^{3+}$ were much stronger than those of the $600-\mathrm{nm}\left({ }^{5} \mathrm{D}_{0} \rightarrow{ }^{7} \mathrm{~F}_{1}\right)$ and 620-nm $\left({ }^{5} \mathrm{D}_{0} \rightarrow{ }^{7} \mathrm{~F}_{2}\right)$ peaks of the film annealed at $900^{\circ} \mathrm{C}$. It seems that energy transfer from $\mathrm{Ce}^{3+}$ to $\mathrm{Eu}^{3+}$ occurs in the film, and much energy is selectively used for the ${ }^{5} \mathrm{D}_{0} \rightarrow{ }^{7} \mathrm{~F}_{4}$ and ${ }^{5} \mathrm{D}_{0} \rightarrow{ }^{7} \mathrm{~F}_{1}$ transitions. 


\section{Acknowledgements}

Part of this work was supported by JSPS KAKENHI Grant Number 26390073; and the “Element Innovation” Project by Ministry of Education, Culture, Sports, Science and Technology in Japan. Part of this work was conducted at the Human Resources Cultivation Center (HRCC), Gunma University, Japan.

\section{References}

[1] Hanaizumi, O., Miura, K., Saito, M., Sato, T., Kawakami, S., Kuramochi, E. and Oku, S. (2000) Frontiers Related with Automatic Shaping of Photonic Crystals. IEICE Transactions on Electronics, E83-C, 912-919.

[2] Sato, T., Miura, K., Ishino, N., Ohtera, Y., Tamamura, T. and Kawakami, S. (2002) Photonic Crystals for the Visible Range Fabricated by Autocloning Technique and Their Application. Optical and Quantum Electronics, 34, 63-70. http://dx.doi.org/10.1023/A:1013382711983

[3] Cid, M., Stem, N., Brunetti, C., Beloto, A.F. and Ramos, C.A.S. (1998) Improvements in Anti-Reflection Coatings for High-Efficiency Silicon Solar Cells. Surface and Coatings Technology, 106, 117-120. http://dx.doi.org/10.1016/S0257-8972(98)00499-X

[4] Zhu, M., Zhang, Z. and Miao, W. (2006) Intense Photoluminescence from Amorphous Tantalum Oxide Films. Applied Physics Letters, 89, Article ID: 021915. http://dx.doi.org/10.1063/1.2219991

[5] Sanada, T., Wakai, Y., Nakashita, H., Matsumoto, T., Yogi, C., Ikeda, S., Wada, N. and Kojima, K. (2010) Preparation of $\mathrm{Eu}^{3+}$-Doped $\mathrm{Ta}_{2} \mathrm{O}_{5}$ Phosphor Particles by Sol-Gel Method. Optical Materials, 33, 164-169. http://dx.doi.org/10.1016/j.optmat.2010.08.018

[6] Singh, M.K., Fusegi, G., Kano, K., Bange, J.P., Miura, K. and Hanaizumi, O. (2009) Intense Photoluminescence from Erbium-Doped Tantalum Oxide Thin Films Deposited by Sputtering. IEICE Electronics Express, 6, 1676-1682. http://dx.doi.org/10.1587/elex.6.1676

[7] Bange, J.P., Singh, M.K., Kano, K., Miura, K. and Hanaizumi, O. (2011) Structural Analysis of RF Sputtered Er Doped $\mathrm{Ta}_{2} \mathrm{O}_{5}$ Films. Key Engineering Materials, 459, 32-37. http://dx.doi.org/10.4028/www.scientific.net/KEM.459.32

[8] Singh, M.K., Miura, K., Fusegi, G., Kano, K. and Hanaizumi, O. (2013) Visible-Light Emission Properties of Erbium-Doped Tantalum-Oxide Films Produced by Co-Sputtering. Key Engineering Materials, 534, 154-157. http://dx.doi.org/10.4028/www.scientific.net/KEM.534.154

[9] Miura, K., Arai, Y., Osawa, T. and Hanaizumi, O. (2012) Light-Emission Properties of Europium-Doped TantalumOxide Thin Films Deposited by Radio-Frequency Magnetron Sputtering. Journal of Light \& Visual Environment, 36, 64-67. http://dx.doi.org/10.2150/jlve.36.64

[10] Miura, K., Osawa, T., Suzuki, T., Yokota, Y. and Hanaizumi, O. (2015) Yellow Light Emission from Ta $\mathrm{O}_{5}: \mathrm{Er}_{\text {, Eu, Ce }}$ Thin Films Deposited Using a Simple Co-Sputtering Method. Results in Physics, 5, 26-27. http://dx.doi.org/10.1016/j.rinp.2014.11.003

[11] Miura, K., Osawa, T., Suzuki, T., Yokota, Y. and Hanaizumi, O. (2015) Fabrication and Evaluation of Green-Light Emitting $\mathrm{Ta}_{2} \mathrm{O}_{5}$ :Er, Ce Co-Sputtered Thin Films. Results in Physics, 5, 78-79. http://dx.doi.org/10.1016/i.rinp.2015.02.002

[12] Du, Q., Zhou, G., Zhou, J., Zhou, H. and Zhan, J. (2012) Enhanced Photoluminescence of CaZrO ${ }_{3}: \mathrm{Er}^{3+}$ by Efficient Energy Transfer from Ce ${ }^{3+}$. Materials Research Bulletin, 47, 3774-3779. http://dx.doi.org/10.1016/j.materresbull.2012.06.022

[13] Roh, J., Hwang, S.H. and Jang, J. (2014) Dual-Functional $\mathrm{CeO}_{2}: \mathrm{Eu}^{3+}$ Nanocrystals for Performance-Enhanced DyeSensitized Solar Cells. ACS Applied Materials Interfaces, 6, 19825-19832. http://dx.doi.org/10.1021/am505194k

[14] Kim, G.C., Mho, S.I. and Park, H.L. (1995) Observation of Energy Transfer between $\mathrm{Ce}^{3+}$ and $\mathrm{Eu}^{3+}$ in $\mathrm{YAlO}_{3}: \mathrm{Ce}, \mathrm{Eu}$. Journal of Materials Science Letters. 14, 805-806. http://dx.doi.org/10.1007/BF00278135

[15] Wang, Y.F., Wang, S., Wu, Z.L., Li, W.R. and Ruan, Y.F. (2013) Photoluminescence Properties of Ce and Eu CoDoped $\mathrm{YVO}_{4}$ Crystals. Journal of Alloys and Compounds, 551, 262-266. http://dx.doi.org/10.1016/j.jallcom.2012.10.042

[16] Rodriguez, V.D., Tikhomirov, V.K., Mendez-Ramos, J., Yanes, A.C. and Moshchalkov, V.V. (2010) Towards Broad Range and Highly Efficient Down-Conversion of Solar Spectrum by $\mathrm{Er}^{3+}-\mathrm{Yb}^{3+} \mathrm{Co}$-Doped Nano-Structured Glass-Ceramics. Solar Energy Materials and Solar Cells, 94, 1612-1617. http://dx.doi.org/10.1016/j.solmat.2010.04.081

[17] Aarts, L., van der Ende, B.M. and Meijerink, A. (2009) Downconversion for Solar Cells in NaYF 4 Er, Yb. Journal of Applied Physics, 106, Article ID: 023522. http://dx.doi.org/10.1063/1.3177257

[18] Ueda, J. and Tanabe, S. (2011) Broadband near Ultra Violet Sensitization of $1 \mu \mathrm{m}$ Luminescence in $\mathrm{Yb}^{3+}$-Doped $\mathrm{CeO}_{2}$ Crystal. Journal of Applied Physics, 110, Article ID: 073104. http://dx.doi.org/10.1063/1.3642984 